\title{
Genesis and development of the spatial structures in former border railway centres Mysłowice - Szczakowa - Granica (Maczki), Poland
}

\author{
Robert Krzysztofik¹, Weronika Dragan¹, Dariusz Gierczak ${ }^{2}$ \\ ${ }^{1}$ Department of Economic Geography, Faculty of Earth Sciences, University of Silesia, Będzińska Str. 60, 41-200 Sosnowiec, \\ Poland \\ E-mail address (corresponding author): robert_krzysztofik@interia.pl \\ ${ }^{2}$ Herder Institute for East-Central Europe Research, Gisonenweg 5-7, 35037 Marburg, Germany
}

\begin{abstract}
The article addresses the question of the emergence of urban centres with a gateway function in the area of contemporary Poland. The work concentrates on three urban centres - Mysłowice, Szczakowa and Granica (Maczki) - which gateway function was conditioned by the existence of railway border crossings in the past that provided services for international transport. The interpretation of settlements and their transformations followed the town plan analysis includes method of Conzen. The article indicates spatial consequences of this kind of function which influenced a significant part of the urban area in the indicated towns. The study highlights the dynamics of spatial changes contemporarily conditioned by the loss of the former gateway function and a fact that role of the border has been marginalized. From the other point of view the decreasing role of the political borders which have become in Europe in most cases barely a symbolic meaning. In the presented case studies the key aspect determining the marginalization of their role in the rail transport system and also their urban development was the change of the political borders and their negative consequences (demolition post-rail areas, formation of functionally derelict areas or depopulation). Former glory and role of these three towns are the still existing railway stations. Fortunately, presented railway stations - their potential and heritage give new possibilities for ideas of functional changes and future development.
\end{abstract}

KEY WORDS: border cities, gateway cities, spatial planning, urban development

\section{Introduction}

Transport infrastructure is one of the most important factors in the formation of cities-. Since the beginning of industrialization, rail transport became one of the main city-forming factors in Europe. Starting from the mid-nineteenth century, it was one of the fundamental features shaping regional urban systems. It was however one of mutual dependence. On the one hand, access to the rail network generated an enormous development potential for an urban place, on the other hand the network was created by taking into account the existing major metropolitan areas and economic regions. From the midnineteenth to the second half of the twentieth century, the railroad in Europe constituted the most important means of inter-regional transport.
The prominence of the railroad led to changes of the physical image of urban settlements (HOHENBERG \& LEES, 1995; KRZYSZTOFIK, 2012). There were only a few examples of poorly connected cities experiencing dynamic growth in the Polish lands in the late nineteenth and early twentieth century, such as Łódź. There were, however, numerous small towns located away from the railway. The railroad had a notable impact as a city-forming factor on settlements located on the intersections of the railway lines with the state border. These places quickly became essential elements of regional urban systems. The meaning of the border towns grew with the growing number of international railway connections passing through the station, especially 
when the general number of border railway crossings was low (BURGHARDT, 1971).

In the second half of the nineteenth and twentieth centuries border railway cities represented one of the largest group of gateway cities, next to seaports (BURGHARDT, 1971; BIRD, 1977; KRZYSZTOFIK, 2004). Their relational functionalism consisted of attempts to achieve benefits from different socioeconomic and technical potentials of two neighbouring countries. The gateway function based on rail transport is particularly relevant for: 1) existing towns with similar functions, but shaped by other transportation ways (Brody, Mysłowice), 2) existing towns, where other means of transport did not lead to the evolution of gateway functions or their impact on it was marginal (Oświęcim), 3) previously less urbanized areas (Katowice, Sosnowiec, Szczakowa), 4) previously unpopulated areas (Granica/Maczki).

Whatever the genetic nature of a gateway city, the function based on the existence of a railway line crossing the state border eventually caused distinct changes in the existing local settlement system. In some cases, such as Katowice or Sosnowiec, it conditioned the dominant role of certain cities in the regional settlement system for several years. The role of a gateway city whose development was based on the railway line crossing the state border was relevant until: 1) abolishing the border or weakening its barrier character, 2) aligning of economic and social potentials of the two neighbouring states, 3) the complete closure of the political border which became impassable, 4) the decline in the importance of the railroad or its liquidation, 5) creation of another centre of a similar nature in the area characterized by better transport accessibility.

The complete loss of gateway functions (as in Mysłowice) usually greatly reduced the development opportunities of the already shaped town. Unless it acquired other functions (mainly manufacturing), it quickly lost its importance and frequently degraded. While dozens of quite large centres based on gateway functions emerged in the territories of contemporary Poland (Katowice, Sosnowiec), only in some of them the causative agent was rail transport (TKOCZ, 1995; CHMIELEWSKA, 2012; KRZYSZTOFIK, 2012). Their gateway functions have expired, mainly due to changes of borders during the first half of the twentieth century. This situation raises a number of consequences, especially regarding the multi-faceted development condition of these centres.

This article refers to three towns located in the Silesian voivodeship: Mysłowice, Maczki and Szczakowa that in the nineteenth and early twentieth centuries experienced brisk development of spatial structures conditioned by the functions of a border transportation centre. These places were located on the border between three important states at that time - Prussia, Russia, and the Habsburg Empire (Austria-Hungary - and represented significant points of international rail transport. Despite many similarities, their development also shows some differences.

For the purposes of this article, detailed studies on urban development of the particular gateway city have been limited to the period before World War I, as the peak time of their prosperity, and the recent trends of regression of the urban fabric. Their entire evolutions were, however, regarded for the explanation of those changes. The interpretation of the three selected urban and spatial systems and their transformations followed the town plan analysis method of CONZEN (1960) which is based on a comparison of cartographic materials (DIE STADT MYSLOWITZ 1911; MAPA KATASTRALNA, 1928; MAPA ZAGŁĘBIA DĄBROWSKIEGO, 1929; MAPA TOPOGRAFICZNA POLSKI, 1996) in chronological order. The morphological analysis was focussed on spatial forms. A critical analysis of the historical maps was backed up by on-site fieldwork (DRAGAN, 2014a) and the inventory of the current status and land-use of selected areas.

\section{Determinants of the spatial development of Mysłowice - Granica (Maczki) - Szczakowa}

Until World War I the towns studied in this article were located in the territory of three European empires of that time whose borders followed along riverbeds of the Czarna Przemsza (Prussia Russia), Przemsza (Prussia - Austria-Hungary) and the Biała Przemsza (Russia - Austria-Hungary) (Fig. 1). At that time, the key events for the formation of the political situation in this region were the First Silesian War (1740-1742), as the western part of Upper Silesia with Mysłowice became Prussian territory, the Congress of Vienna (1815) which decided upon the redistribution of the territories annexed in the partitions of Poland (1772-1795) and led to the establishment of the initially autonomous Kingdom of Poland (also called Congress Poland) in the Russian Empire, as well as the annexing of the Free City of Cracow, which was also created in the aftermath of the Congress of Vienna, by the Habsburg Empire in 1846 (SUliK, 2007; DraGan, 2014). As a result of these events the case study towns belonged to three different countries with various levels of economic and social development. This contributed to the permanent border movements 
of people and goods. Mysłowice was located on the Prussian side, Szczakowa in Austria-Hungary (until 1846: Free City of Cracow), and Maczki in the Russian Empire.

Another important city-forming factor in the late nineteenth and early twentieth century was the development of the railroad. It contributed to the urbanization of the surrounding area (KRZYSZTOFIK, 1998) and affected an increase in the rank of towns, particularly with junctions and larger stations, like Mysłowice, Szczakowa and Granica (Maczki). On the one hand, the expansion of the railway network of the German Union facilitated fast transportation of the goods needed for the quickly proceeding industrialisation, on the other hand, it determined the increasing demand for coal, steel, and iron (MyszcZYsZYN, 2013). The
Upper Silesian Coal Basin in Prussia was connected via the Upper Silesian Railway, which in 1846 ended in Mysłowice, connecting this border station with Wrocław and Berlin (TAYLOR, 2007). Branch lines were built in 1859 to Bierun, and in 1863 to Oświęcim in the Habsburg Empire, but the first connection with the Austro-Hungarian rail network via Mysłowice (and Szczakowa) was made in 1847, thanks to the completion of the Cracow-Upper Silesian Railway. The most important line of the Habsburg Empire was however the Emperor Ferdinand Northern Railway running from Vienna, via Dziedzice, Oświęcim, and the border station in Szczakowa (1848) to Cracow. Later in the same year, a connection Szczakowa Granica (Maczki) was opened, due to which Warsaw became connected to Vienna (Fig. 1).

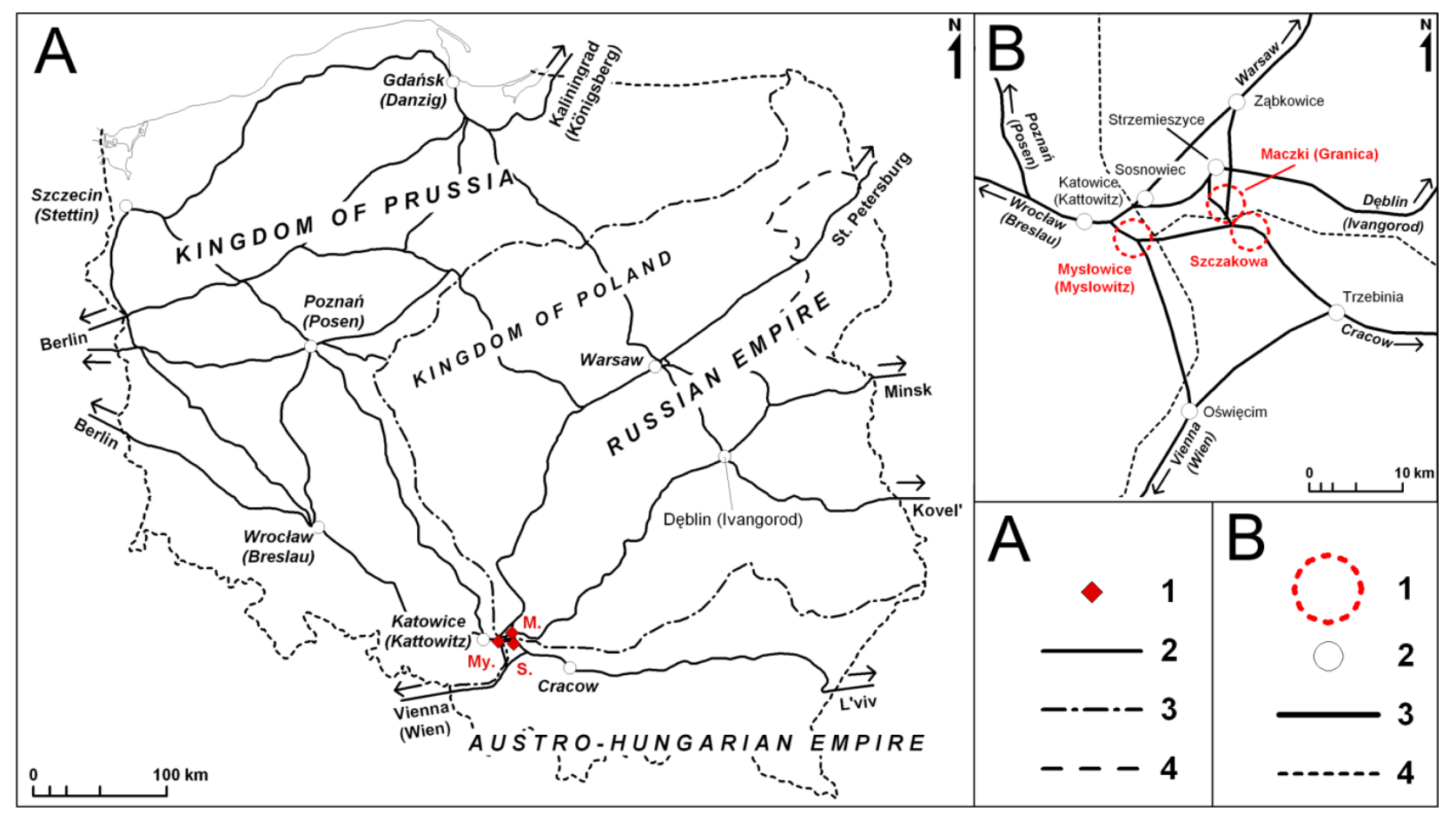

Fig. 1. Location of the case study towns against the background of contemporary and partitioning boundaries(A) and the railway network in their proximity (B)

A: 1 - researched towns; 2 - main railway lines; 3 - national boundaries during the partition period; 4 - boundary between the Kingdom of Poland (an autonomous part of the Russian Empire) and Russia; B: 1 - researched stations; 2 - other important stations; 3 - railway, 4 - boundaries during the partition period; My - Mysłowice (Myslowitz), M - Maczki, S - Szczakowa

As a result, the role of Granica as a border station in Russia (the Polish Kingdom) on the Warsaw-Vienna Railway and Szczakowa as a rail hub for lines from Wrocław, Cracow and Vienna increased. When in 1859 the Warsaw-Vienna Railway branch line from Ząbkowice via Sosnowiec to Katowice was accomplished, which allowed the bypass of Granica and Szczakowa and thus greatly reducing the journey from Russia to Prussia, the function of Granica decreased. Despite the common conditions and factors affecting urbanization as well as the functional development of Mysłowice, Szczakowa and Granica (Maczki), however, they these processes took a slightly different course in the particular case study towns.

\section{Development of the spatial structure of Mysłowice}

Mysłowice (German: Myslowitz) is the only case study town which had urban character before the railroad was built. Mysłowice was located as a city on the so-called Magdeburg law, most probably in the thirteenth century, the exact 
date is not known. The city was located between the river Przemsza in the east and vast areas of forest in the west, while to the north and south it was surrounded by arable land, orchards and pastures (DRAGAN, 2014b). In 1742, Mysłowice, along with the bulk of Silesia, became a part of Prussia, and the city was then demoted to the status of a market town.

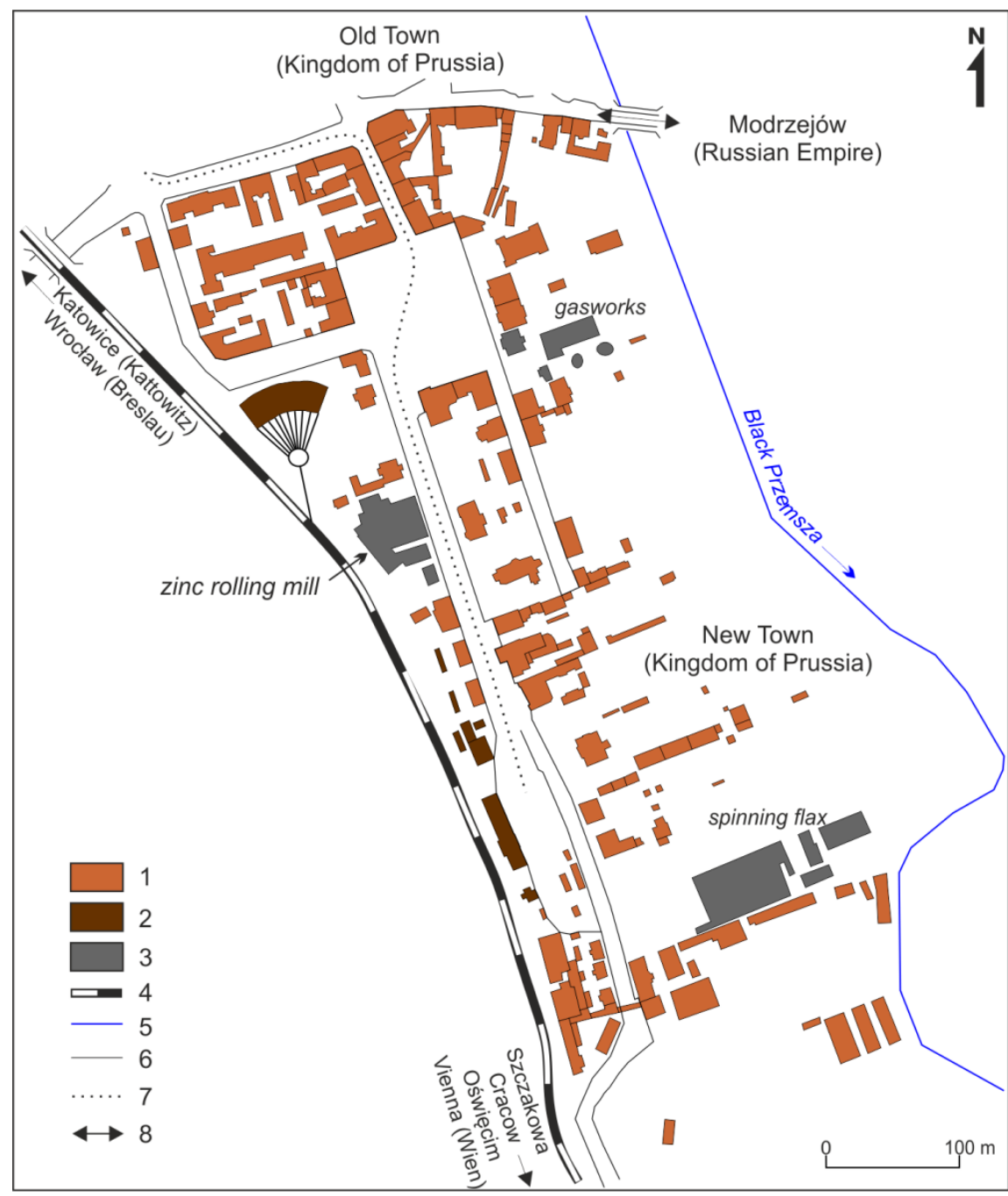

Fig. 2. Spatial arrangement of the New Town area in Mysłowice at the beginning of the $20^{\text {th }}$ century

1 - dwelling houses and public buildings; 2 - railway buildings; 3 - industrial buildings; 4 - railway line; 5 - river; 6 - streets; 7 - tram line; 8 - border crossing between Prussia and the Polish Kingdom (Russia)

The turning point for the economic situation of the town was the previously mentioned Wrocław - Mysłowice railway line, which opened in 1846, then extended to Szczakowa (1847) and Oświęcim (1863). Coincident with the railway junction, the railway station also emerged (DRAGAN, in press). This resulted in the functional and spatial expansion of the town, in which wooden buildings were replaced by brick and masonry ones, and in the location of the new border and logistical functions near to the station, south of the historic centre. The still noticeable spatial duality of the city of Mysłowice was shaped in this way - with the Old Town area (location) and the New Town area (related to the railway station). Due to the effect of the dynamic economic development and spatial expansion,
Mysłowice regained its municipal rights in 1861. In New Town at the freshly created central square - Wilhelmsplatz (currently Wolności Square), also called New Market, the new town hall was built, irretrievably depriving the former market of its administrative functions (DRAGAN, 2014a). The Municipal High School for Girls, an elementary school, the synagogue, and the gasworks were established along the frontage of New Market. In the south-western corner of the square the exclusive Bahnhofstraße ("station street", now Powstańców street) started. Villas that belonged to prosperous citizens were situated along the street, as well as the Mühle Hotel and a Lutheran Church. This street led to the passenger terminal building, with the final stop of the tram line from Katowice in front of it (Fig. 2). Bahnhofstraße was 
extended as Poststraße (now part of Powstańców Street) from the Imperial Post Office building to the complex of the Great Emigration Office. This complex housed barracks for emigrants, the border office and the registration office building with the Bahnhof Hotel. Also the Hamburg Ship Society (HAPAG) and a subsidiary of the German

Central Station of Agricultural Workers had their headquarters at Bahnhofstraße. These institutions organized trips to America and for agricultural work in Western Europe. Emigration halls were located opposite the whole complex, with a separate platform designated for this service. Mysłowice, in the research period, constituted a gateway, especially for the residents from rural areas of Eastern and Southern Europe, who contributed to the broad immigration stream (DRAGAN, 2014b).

Its specific location in the border triangle between the European empires led to the growing importance of Mysłowice in economic and social terms, and also as a market place. The transit traffic through the Mysłowice freight station increased, as well as the rapid development of shipping companies, especially transporting agricultural goods from Galicia to Prussia and industrial goods in the opposite direction. In addition, a municipal slaughterhouse was established and the quarantine station for cattle and pigs was moved here from Oświęcim (SULIK, 2007). Mysłowice emerged as a specialized trade centre for the slaughter of animals in the late nineteenth and early twentieth centuries (KANTORPiETRAGA \& KRZYSZTOFIK, 2011).

The railway buildings included the previously mentioned passenger and freight stations along with its extension in the north-west, constituting a siding of the "Mysłowice" hard coal mine. The station complex also housed a roundhouse. Along with the growing importance of the railway junction, the demand for railway employees also increased. Several buildings were erected at Bahnhofstraße and Poststraße especially for them, thereby contributing to the urban sprawl of the New Town district. A building for railway officials was erected at the station square, where the subsidiary board of the Austro-Hungarian Emperor Ferdinand Northern Railway was also located.

After World War I, Mysłowice lost its border function due to the shift of the state border by several kilometres to the west. In the inter-war period the first demolition of some post-railway buildings took place, but this practice was observed on a large scale only after 1945 . It largely resulted from the mono-functional direction of the economy of the city which was focused on the mining industry. As a result, the technical condition of the urban fabric deteriorated, when the new economic paradigm entered into force after World War II. In the 1990s the economic situation of the city and rail transport radically worsened and further degradation of the railway areas began (Fig. 3). Passenger and rail freight traffic has been decreasing, particularly on longdistance routes.). The roundhouse was first transformed into a depot, which was then shut down. Its buildings are currently vacant. In addition, the passenger terminal has been largely excluded from use in 2012 as the waiting room and ticket office were closed. Although, some of the rooms were rented for other services (a Pentecostal church, an antique shop with a café), they do not have a dynamic impact on the neighbouring areas. Mysłowice has entered a negative path of development due to these changes, and the Old Town district is the main problem area of the city (GWOSDZ, 2004; DRAGAN, 2014b).

\section{Development of the spatial structure of Szczakowa}

The origins of the town of Szczakowa date back to the village founded at the turn of the thirteenth and fourteenth centuries, situated on the trade route from Cracow to Będzin, at the foot of the hill called Góra Piasku near the Kozi Bród stream. At that time, most of the inhabitants of Szczakowa were engaged in agriculture. The buildings of the village developed slowly along the main road, creating a chain system (LEŚRUNICKA, 2008; TATARCZUCH, 2005).

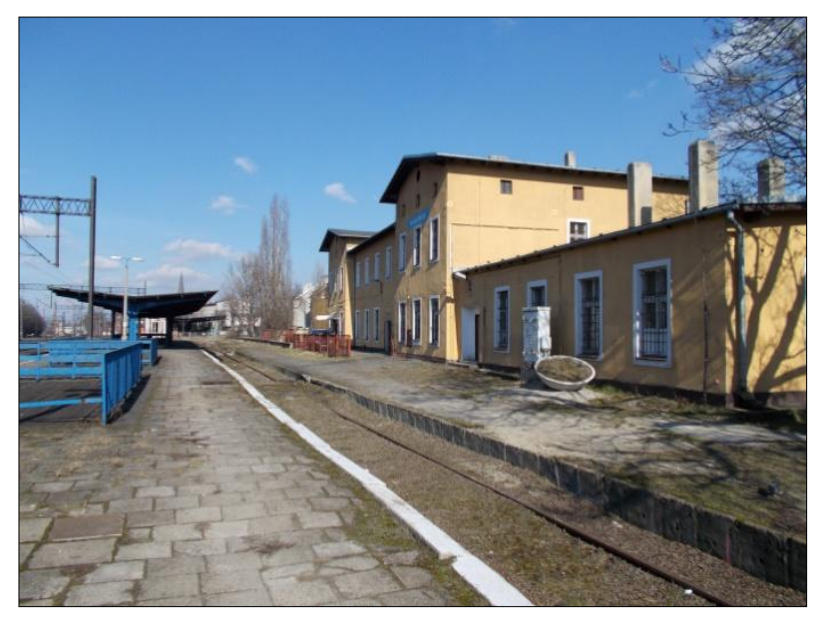

Fig. 3. The railway station building in Mysłowice, 2014 (W. Dragan)

The formation of the Austro-Russian border along the Biała Przemsza river in the beginning of the nineteenth century caused an expansion of the development of the original village of Szczakowa in 
a north-east direction, on previously unoccupied land (i.e. Piasek), mainly along the present Jagiellońska Street. However, the mere proximity of the border did not trigger the urbanization process as much as the establishment of the opening of the railway line Cracow - Szczakowa (Austria-Hungary) - Mysłowice (Prussia) and the railway station in 1847. The expansion of an adequate urban infrastructure did not keep pace with the rapid spatial growth of the settlement the population faced problems such as the lack of streets or too narrow streets, lack of sewerage and water supply (TATARCZUCH, 2005). The specificity of the settlement was its border location and the creation of an international railway hub in 1848, as the Warsaw-Vienna line was connected with the station in Granica. This led to steady migration streams between the Russian Kingdom of Poland and the Austro-Hungarian New Galicia. There were many forms of movements observed at this border station, from episodic, through daily and seasonal, to permanent migration. One of the initial consequences of the steady migrant influx was the shortage of free areas for development, as the settlement occupied the area bounded by the railway line, the River Biała Przemsza, and the Kozi Bród stream. Also a housing shortage became a challenge. The deficiencies caused a change in the type of real estate development from single floor to two-floor tenement housing (TATARCZUCH, 2005). Also at that time, the transit movement of goods from Lviv via Cracow to Silesia as well as from Galicia via Prussia to Austria and the Czech Republic became more intense. In addition to the railway station building, new dwelling houses for railway workers were erected. During the expansion of the station, a storage warehouse, a new collection of tracks and humps, a wagon weight house, a water tower (TATARCZUCH, 2005; GUTOWSKI, 2006), railway workshops, and a roundhouse were built (Fig. 4). Szczakowa became the place, where the lines connecting the capitals of the three great powers - Berlin, St. Petersburg and Vienna - met (LEŚ-RUNICKA, 2008).

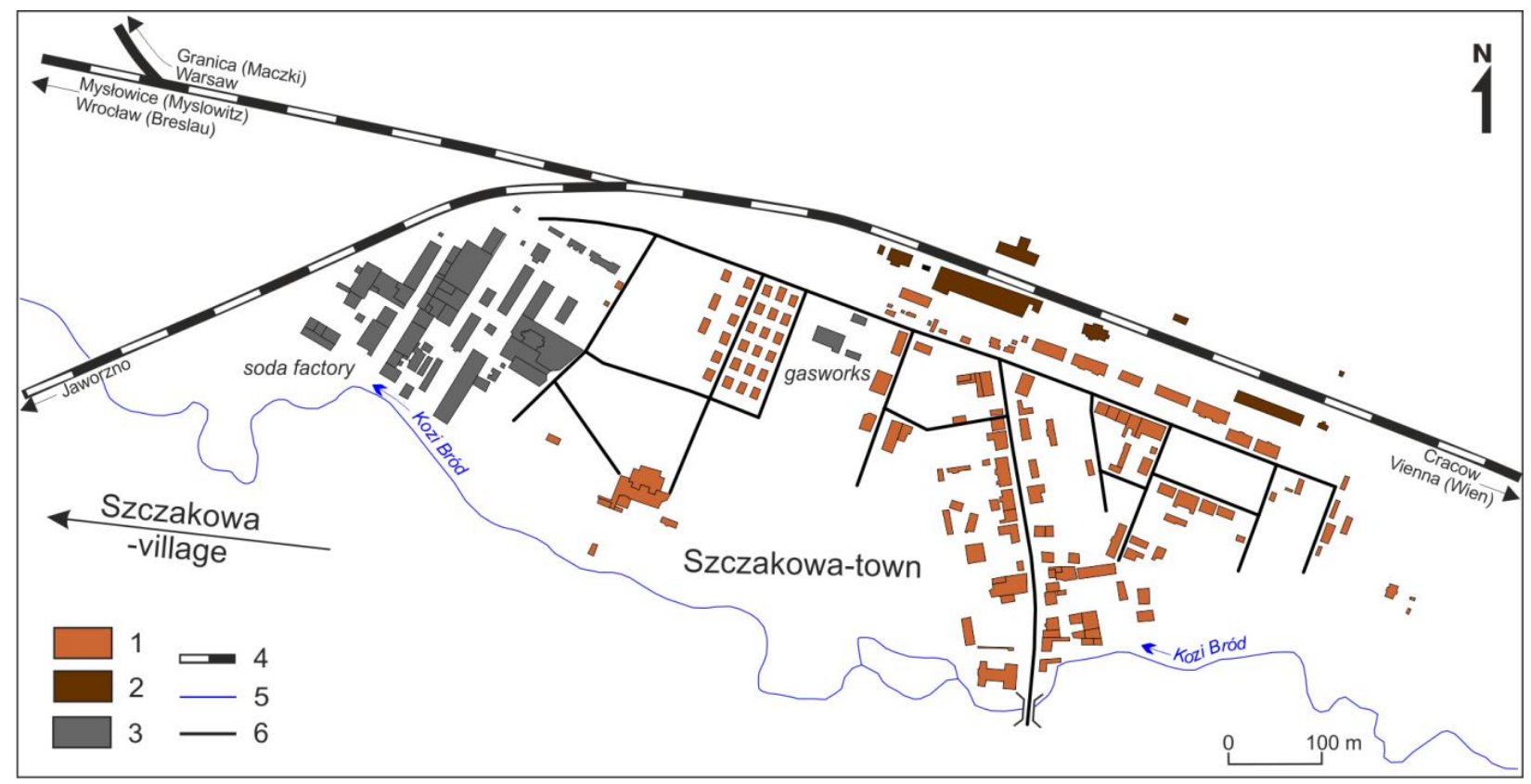

Fig. 4. Spatial arrangement of Szczakowa in the late nineteenth century

1 - dwelling houses and public buildings; 2 - railway buildings; 3 - industrial buildings; 4 - railway line; 5 - stream; 6 streets

Along with the establishment of the border station, Szczakowa's economy experienced a remarkable growth by gaining new functions, i.e. border and transportation. The development of shipping companies was initiated and the regional custom office, as well as postal and telegraph stations were installed in the settlement. A state police station was in operation and also barracks for troops stationed in the Austro-Hungarian army were located near the train station (GuTOWSKI, 2006; LEŚ-RUNiCKA, 2008). The dynamic urban and functional development led to granting Szczakowa municipal rights in 1896.

In addition to the functions of border and transportation in forming the city industry also developed here, which contributed to an urban revival of the town. The very origins of industry in Szczakowa were linked with coal mining and 
dated back to the eighteenth century (LEŚRUNICKA, 2012). However, a significant boom in industrial activity was associated with the development of large-scale shipping companies. One of the first production activities started in 1883 when the First Portland Cement Factory for Lime and Bricks was established. Its complex was built in the eastern part of the town, and it was followed by the construction of a number of houses for its staff. The workers' colony eventually formed the hamlet of Pieczyska (TATARCzUCH, 2005). Furthermore, this factory depended on limestone and dolomite from the local quarries in the surrounding areas of Szczakowa. Another important plant depending on the local limestone was the CK Privileged First Austrian Factory of Ammoniacal Soda of the Jaworzno Guild which was founded in 1885 in the western part of the town. This plant was in operation until 1909 and was also strongly connected with the train station which allowed delivery of raw materials and export of finished products (TATARCZUCH, 2005). When the former soda factory closed down, its building was adapted for use as a glassworks in 1911. Furthermore, within the case study area a gas plant operated from 1890 providing lighting for the whole town. In the inter-war period, a steam sawmill and a bakelite products factory were built on this site.

Szczakowa, like the other two case studies, lost its border position in 1918. Its economy has been largely based on industry since then. During World War I, in 1917, the Paper Products Works was established in Szczakowa. A tannery was established there in 1929 and it developed strongly during World War II.

During the period of the centrally planned economy after 1945 further industrial investments were carried out and a new type of housing construction was introduced. A glass factory, a cement factory, a bag manufacture, tanneries, and iron foundries developed in this period. In addition, the exploitation of filling sand was started. The workers' housing estate for the employees of these plants was built at Kolejarzy Street. The urban fabric of Szczakowa has been complemented with large prefab houses like those of Gagarin district in Jaworznicka Street.

As a result of the spatial expansion of Szczakowa, the original settlement - Szczakowavillage - was eventually incorporated into the town. Due to the top-down administrative decisions in 1956, Szczakowa was incorporated into the city of Jaworzno and currently functions as its peripheral district. Today, the urbanized area of Szczakowa is characterized by regressive processes. Deteriorated buildings and infrastructure facilities have become a standard there. The railway station presents, however, the worst picture. The passenger station was in fact restored, but the renovation mainly focussed on the elevation, while the large station building itself has experienced gradual degradation (Fig. 5). The old railway buildings, including the water tower, have either been virtually destroyed or, like the original roundhouse, were demolished in earlier periods as a result of multiple reconstructions of the railway station area. As in the case of Mysłowice, contemporary passenger traffic has steadily reduced. to about $30 \%$. The railway infrastructure in Szczakowa is stabilized by the existence of a large goods marshalling yard and the still active locomotive depot, which, however, has been relocated from its original position.

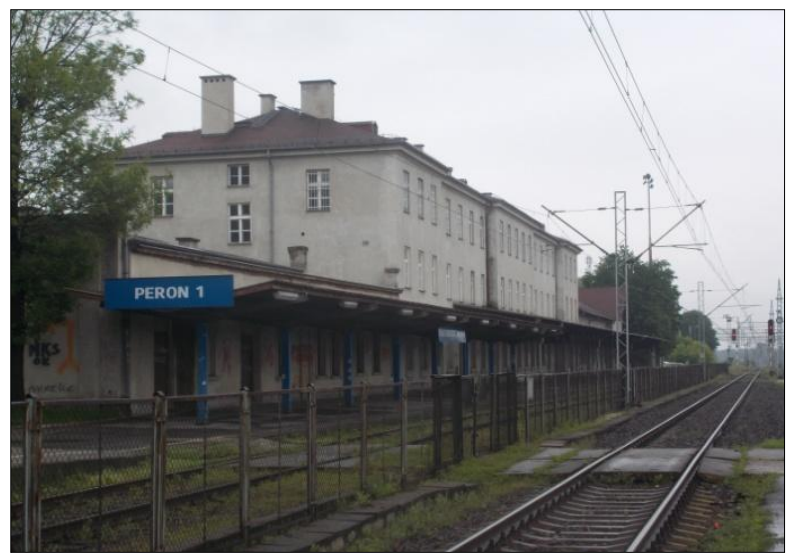

Fig. 5. The railway station in Szczakowa in 2014 (W. Dragan)

\section{Development of the spatial structure of Granica (Maczki)}

In the Kingdom of Poland under Russian rule, the final border station (hence the name of the town - granica $=$ "border") with Austria-Hungary on the Warsaw-Vienna line was Granica (presently Maczki). In contrast to the previously studied Mysłowice and Szczakowa, it was strictly a railway settlement, located near the agricultural hamlet of Porąbka-Maćków (presently Stare Maczki) (SZAJNOWSKA-WYSOCKA \& KULESZA, 2007). The station gave its name to a settlement, which was built from the grounds amid a forest. The central element of the newly established settlement was a monumental railway station which clearly dominated the urban space. The station building was located between the railroad tracks looking away from the settlement, while the other buildings faced the station (SKWARA, 2003). The railway station, as mentioned above, presented a type of island with two platforms on both sides; one was bound for arrivals from Russia, while the other for 
departures to Szczakowa in Austria-Hungary (KUROWSKA-CIECHAŃSKA \& CIECHAŃSKI, 2011). It was the only railway station of its kind on the Warsaw-Vienna line (PASZKE, 1995). Although its complex was opened as early as 1848, the station building took its final shape in the late nineteenth century. Inside the station, in addition to the waiting room and a buffet, there was a telegraph office and apartments designated for the single visit of the tsar and his family. An interesting, yet important issue was the presence of the ticket offices for the Austro-Hungarian Privileged Emperor Ferdinand Northern Railway which confirmed the importance of the station and its frontier character. It is worth mentioning that the architectural style of the station was the work of the well-known architect of Italian origin, $\mathrm{H}$. Marconi. Besides the station building, there was a roundhouse, a depot, a customs house (to the south-west side of the station), and a control room located at the border bridge on the Biała Przemsza in the vicinity of the station. Moreover, Granica had a gas plant and a water tower which were crucial to sustaining passenger transportation (SKWARA, 2003).

The railway station in Granica was created for large-scale transit movement. It included both the migration of the populations switching between trains on international routes as well as the transshipment of goods for which the warehouses were built. Travellers from Warsaw going to Cracow, arrived at the station in the evening, while the connecting train to their destination left in the morning. In turn, people travelling to Vienna and Wrocław transferred to the train to Mysłowice, where they stayed for the night (SoIDA, 1997). Thus, passengers using the Granica station were forced to spend the night in the local hotel which was established in 1856.

The development of the border station and migration contributed to an increase in the population of Granica and to the necessity to expand this railway settlement. Dynamic construction movements took place in the 1870 s when residential buildings were erected on the present day Krakowska Street. In the 1880s, a number of dwelling houses for railway workers were built on the east side of the railway station. In the meantime, barracks for the army, Border Guards, and chamber staff were created in the southwestern part of the settlement (SKWARA, 2003).

An important investment that contributed to the development of the industry in the Dąbrowa Basin was the Ivangorod-Dąbrowa Rail Route, connecting Ivangorod (now Dęblin) with Dąbrowa (now Dąbrowa Górnicza). In 1885, this railway reached Strzemieszyce (now a district of Dąbrowa Górnicza), where it separated into two branches the one led to Sosnowiec (now the South Station of Sosnowiec) and continued to Prussia, while the other ended in Granica (SOIDA, 1997; NADOLSKI, 2012). For the purpose of the Ivangorod-Dąbrowa line, a broad gauge railway station was build west of the regular gauge stations, which had been established on the Warsaw-Vienna line (SoIDA, 1997). It was the final freight station with its own warehouses, depots and sidings, a salt station, and trans-shipment lanes. Two shipping companies started their operations in the direct proximity of the railway station (Fig. 6). The construction of the new line contributed to the urban expansion of Granica, and the need for more dwelling houses for railroad workers. They emerged on the recent Stacyjna Street and Kadłubka Street (western part of the settlement) (PISALSKI \& PODLEJSKI, 2006).

The economic situation of the settlement weakened in 1859, as the Ząbkowice - Katowice via Sosnowiec railway line (now the Central Station of Sosnowiec) was finished and the role of the Granica (Maczki) station significantly decreased. The total loss of its function as a border station occurred with the end of World War I due to the change of the state border. An important investment in the inter-war period was the construction of the Water Supply Plant "Maczki" (1929), as well as the accompanying dwelling housing for its employees, which supplied the Dąbrowa Basin and Szczakowa with water. The destructions of World War II period hit especially the historic railway facilities including the Ivangorod-Dąbrowa Railway Station. Further urbanization processes were connected with the location of new companies and plants in the Maczki area. After 1945 the building of the railway station was adapted for the Railway Printery. In the 1950s, an iron ore landfill was established in the western part of the settlement, along with blocks of flats for its workers. In 1958, Maczki received the status of an urban settlement; in 1973, it became a part of the town of Kazimierz Górniczy and in 1975 they were both incorporated into the city of Sosnowiec.

Recently Maczki is one of the peripheral districts of Sosnowiec, separated from its centre by a large forested area. An undisputed dominant feature in the landscape is the railway station, currently undergoing a drastic decline (Fig. 7). The remainder of the old buildings (locomotive depot, water tower, customs houses) are in a similar state. The complex of the former broad-gauge freight station was completely destroyed and turned into wasteland. 


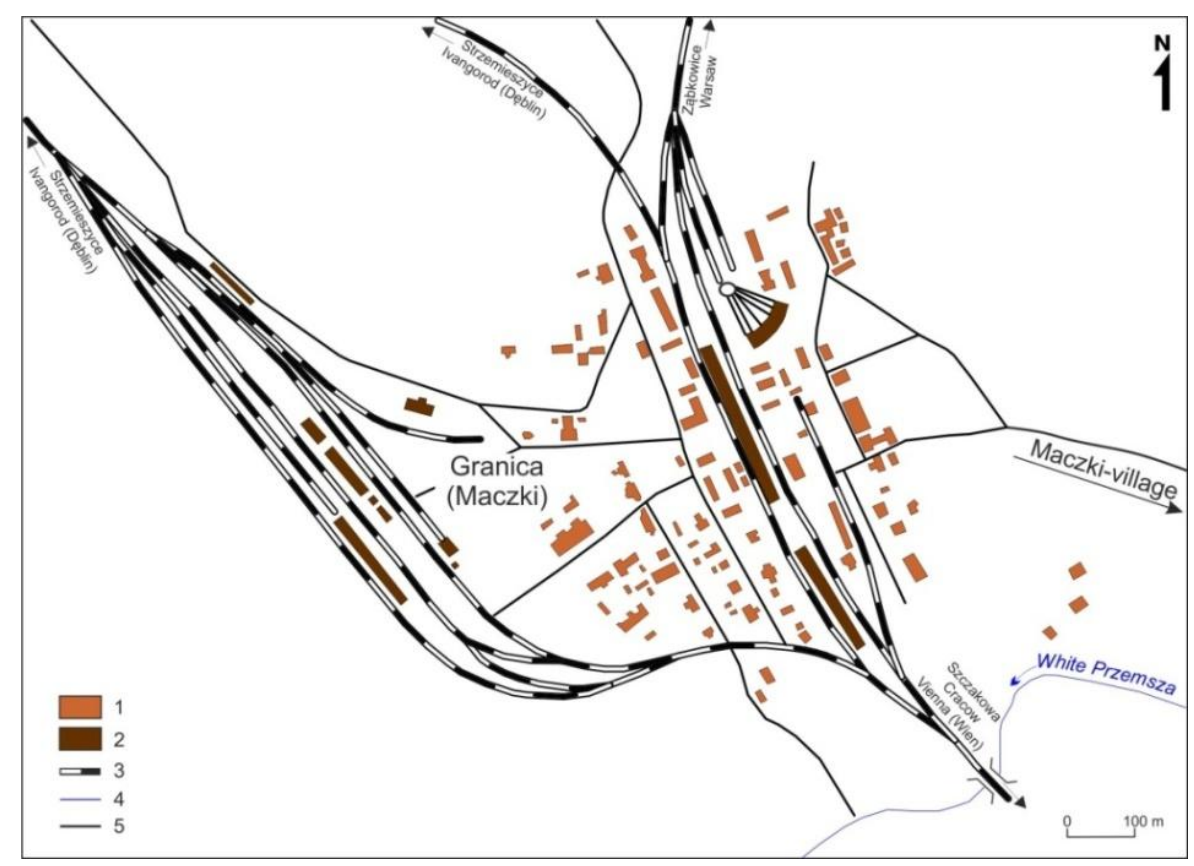

Fig. 6. Spatial arrangement of Granica (Maczki) in the late nineteenth century

1 - dwelling houses and public buildings; 2 - railway buildings; 3 - railway line; 4 - river; 5 - streets

Passenger traffic on the Jaworzno Szczakowa Sosnowiec Maczki - Dąbrowa Górnicza Ząbkowice line has clearly decreased (only regional passenger connections), and passenger trains have not stopped at the station mentioned since 2009. The landscape of the area depicts a mixture of nineteenth century buildings, residential buildings of the inter-war period, single-family houses and blocks of flats from the period of the centrally planned economy and its industry. This affects the spatial order and the aesthetic appearance of Maczki. In addition, there are numerous vacant buildings and ruins, as well as the ubiquitous remains of railway infrastructure. The local functional structure has also been visibly weakening, as the offered service has been reduced to the basic needs (mostly grocery stores).

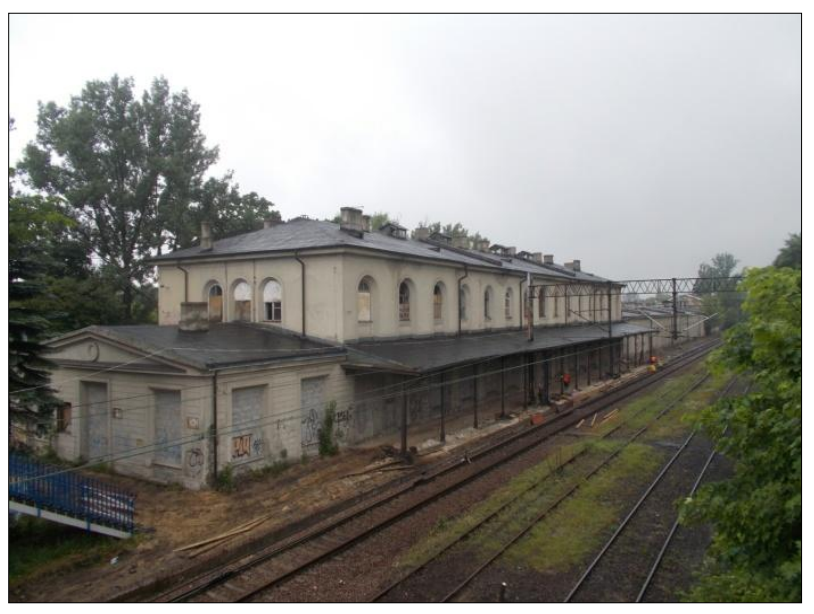

Fig. 7. The railway station in Maczki (Sosnowiec) in 2014 (W. Dragan)

\section{Conclusions}

Border functions of towns located on the major routes of the railroad were one of the key features determining the formation and development of urban settlements in the nineteenth and the first half of the twentieth century. Over 150 years, from being a driving factor in progress (next to industrial and capital functions), they have become less important or even marginal. This is relevant to a number of locations in Poland. There are several reasons for this development.

Firstly, the role of rail transportation has diminished. A significant part of it has been taken over by automotive and aviation transportation, respectively. Also the organization of the border controls for rail traffic has changed. A large part of these take place actually on the train. Lengthy stops at the border stations are no longer required or even desired, since the time factor has become important component of the competition between different modes of transport. Particularly since the end of the twentieth century, there have been actions aimed at improving rail transportation in this respect. The role of the border crossing has been marginalized.

Secondly, the decreasing role of the political borders in Europe in most cases now have only a symbolic meaning. Hence, the connection of two linear systems, i.e. the border and the transportation, which had been so important one hundred years ago, have now lost their original impact. 
In the discussed case studies the key aspect determining the marginalization of their role in the rail transport system and also in their urban development was the change of the political borders. The current picture of these changes and the role of the former border cities located on important rail routes is characterised not only by the degradation of the railway infrastructure but also of the areas surrounding the railway stations. The whole towns have been hit by recession. Typical phenomena in these places in the last 2030 years have been population losses, the elimination of industrial functions for which the railway used to be the attracting factor, the formation of functionally derelict areas like brownfields and post-rail greyfields, the degradation of the housing stock, and problems of social exclusion as well as of unemployment.

The still extant railway stations are a testimony to the former glory and role of these case study cities. Unfortunately, they are significantly neglected. These stations, as well as the preserved railway and other infrastructure facilities accompanying the former border crossing functions, should be a valuable evidence of the past of these cities and their local regions that have undergone the stage of development in their history as a gateway city.

Hopes for the former railway buildings and surrounding residential areas is that they are able to adopt new functions. Currently, their role in perpetuating the material heritage of the past economy is limited. The greatest hopes are represented by such projects as the plan to adapt the railway station in Sosnowiec-Maczki into a Scientific and Educational Centre for Railway Transport of the Silesian University of Technology.

\section{References}

Bird J. 1977. Centrality and Cities. Routledge Direct Ed., London, Henley, Boston.

Burghardt A. 1971. A Hypothesis about Gateway Cities. Ann. of the Assoc. of American Geogr., 61, 3: 269-285.

Chmielewska M. 2012. Current changes in morphology of the city center of Katowice, Acta Geogr. Silesiana, 11: 5-14.

Conzen M. R. G. 1960. The Plan Analysis of an English City Centre. [in:] K. Norborg (ed.), Proc. of the IGU Symp. in Urban Geography Lund 1960, Lund Stud. in Geogr., Ser. B. Human Geography, 24: 383-414.

Die Stadt Myslowitz 1911. Map - scale about 1:6 300.

Dragan W. 2014a. Funkcjonalna i przestrzenna transformacja Rynku w Mysłowicach od czasów feudalnych do współczesności [in:] Sitek S. (ed.) Nowe i stare" problem badawcze w geografii społeczno-ekonomicznej. PTG, Oddz. Katowice, Sosnowiec (in press).

Dragan W. 2014b. Funkcjonalna i przestrzenna transformacja Starego Miasta w Mysłowicach w okresie 1913-2013. WNoZ Uniw. Śląski, Sosnowiec (script of the MA thesis).
Gutowski D. 2006. Zarys dziejów kolei w Szczakowej. Zesz. Historyczne Miasta Jaworzna, 10: 50-53.

Gwosdz K. 2004. Ewolucja rangi miejscowości w konurbacji przemysłowej. Przypadek Górnego Śląska (1830-2000). IGiPZ UJ, Krakow.

Hohenberg P., Lees L.H. 1995. The Making of Urban Europe 1000-1994. Harvard Univ. Press, Cambridge, London.

Kantor-Pietraga I., Krzysztofik R. 2011. Zmienność funkcji miasta i przestrzeni publicznej na przykładzie Mysłowic 1911-2011 [in:] Jażdżewska I. (ed.) XXIV Konwersatorium Wiedzy o Mieście, Wyd. Uniw. Łódz., Łódź: 245-256.

Koter M. 1994. Od fizjonomii do morfogenezy i morfologii porównawczej. Podstawowe zagadnienia teoretyczne morfologii miast [in:] Koter M., Tkocz J. (eds.), Zagadnienia geografii historycznej osadnictwa w Polsce. Wyd. UMK, Wyd. Uniw. Łódz., Toruń-Łódź: 23-32.

Krzysztofik R. 1998. Wpływ linii kolejowej warszawskowiedeńskiej na urbanizację okolicznych terenów (Odcinek: Sosnowiec-Częstochowa). [in:] Ekspres Zagłębiowski. Mat. pomocnicze do nauki o regionie, 9 (101): 16-21.

Krzysztofik R. 2004. Miasta - wrota. Zarys teorii i przegląd badań [in:] Czas. Geogr., 75, 3: 213-231.

Krzysztofik R. 2012. Umiastowienie obszaru Polski od XIII do XXI wieku. Interpretacja geograficzno-historyczna. Wyd. Nauk. "Śląsk", Katowice.

Kurowska-Ciechańska J., Ciechański A. 2011. Koleje w Polsce: parowozy, wąskotorówki, dworce i muzea. Carta Blanca, Warszawa.

Leś-Runicka M. 2008. Z dziejów wsi i miasta Szczakowa. Zesz. Historyczne Miasta Jaworzna, 11: 32-38.

Leś-Runicka M. 2012. Kopalnia w Szczakowej. Pierwsza kopalnia węgla kamiennego w Polsce. Zesz. Hist. M. Jaworzna, 13: 3-12.

Mapa Katastralna (największe zakłady), na podstawie mapy z 1895 roku, podziałka 1:2 880, Kraków, 1928.

Mapa topograficzna 1:10 000, ark. Mysłowice. Warszawa, 1996.

Mapa Zagłębia Dąbrowskiego 1: 10 000, WIG, Warszawa, 1929.

Myszczyszyn J. 2013. Wpływ kolei żelaznych na wzrost gospodarczy Niemiec (1840-1913). Wyd. Uniw. Łódz., Łódź.

Nadolski P. 2012. Dzieje kolei normalnotorowych na obszarze byłej Śląskiej Dyrekcji Okręgowej Kolei Państwowych [in:] Keller D. (ed.) Dzieje kolei w Polsce. Eurosprinter, Muzeum w Rybniku, Rybnik: 109-130.

Paszke A. 1995. Stacje i przystanki. [in:] Paszke A., Jerczyński M., Koziarski S. M. (eds.) 150 lat Drogi Żelaznej Warszawsko-Wiedeńskiej. Warszawa: 135-152.

Pisalski G., Podlejski Ł. 2006. Juliusz - Kazimierz Górniczy Maczki - Ostrowy - Porąka. Od tradycji do nowoczesności. "Adore", Dąbrowa Górnicza.

Skwara A. 2003. Morfogeneza Maczek od poczatków XVIII wieku do czasów współczesnych. WNoZ Uniw. Śląski, Sosnowiec (script of the MA thesis).

Soida K., Karniewski J., Roszka T., Dąbrowski H., Podlejski Z., Szafirski T. 1997. Dzieje Katowickiego Okręgu Przemysłowego. Śląska Dyr. Okręgowa Kolei Państ., Katowice.

Sulik A. 2007. Historia miasta Mysłowice do 1922 roku. UM w Mysłowicach, Mysłowice.

Szajnowska-Wysocka A., Kulesza M. 2007. Studia społeczne $i$ przestrzenne ośrodka przemysłowego (na przykładzie Sosnowca), Wyd. Uniw. Łódz., Łódź.

Tatarczuch A. 2005. Monografia Szczakowej. Zesz. Historyczne Miasta Jaworzna, 9: 5-60.

Taylor Z. 2007. Rozwój i regres sieci kolejowej w Polsce. Monografie IGiPZ PAN. 7. IGiPZ PAN, Warszawa.

Tkocz M. 1995. Katowice jako ośrodek regionalny w latach 1865-1995, Wyd. "Śląsk", Katowice.

Wojtoń A. 2003. Morfogeneza Szczakowej od XIII wieku do współczesności. WNOZ Uniw. Śląski, Sosnowiec (script of the MA thesis). 